\title{
Identification and purification of inhibin and inhibin-related proteins
}

\author{
P. G. Knight \\ Department of Blochemistry \& Physiology. The University of Reading, P.O. Box 228. \\ Whiteknights, Reading RG6 2AJ, UK
}

Keywords: inhibin; activin; follistatin; isolation; characterization

\section{Introduction}

Within the past 5 years the existence of 'inhibin' has been proven conclusively. After many decades of uncertainty surrounding this putative non-steroidal mediator of gonadal negative feedback, inhibin has been purified to homogeneity, its physico-chemical and biological properties defined, the genes encoding its subunits cloned and sequenced and its physiological role(s) examined in detail. A useful working definition recently proposed by Burger (1988) states that "inhibin is a glycoprotein hormone consisting of two dissimilar disulphide-linked subunits termed $\alpha$ - and $\beta$ which inhibits pituitary gonadotrophin production and/or secretion, preferentially that of FSH". The literature relating to the discovery, isolation and characterization of inhibin has been reviewed extensively in the past few years and the reader will find much additional information in comprehensive reviews by Findlay (1986), de Jong (1987, 1988), Ying (1988) and Lincoln et al. (1989).

\section{Inhibin}

\section{Identification of inhibin}

Whilst the concept that the gonads secrete a non-steroidal factor capable of suppressing pituitary gonadotrophin secretion arose over sixty years ago (Mottram \& Cramer, 1923; McCullagh, 1932), interest in inhibin remained at a relatively low level for many years. The advent of radioimmunoassays for the measurement of LH and FSH in the early 1970 s prompted, amongst other things, renewed interest in the 'inhibin-concept' and it was soon established that various gonadally-derived fluids of both male (e.g. rete testis fluid, testicular lymph, seminal plasma) and female (e.g. ovarian follicular fluid) origin contain demonstrable inhibin-like biological activity (ILA). These early observations prompted several research groups to attempt to purify the active principle from one or other of the sources identified. However, it was not until 1985 that this task was accomplished.

\section{Purification of inhibin}

It is worth considering, with the benefit of hindsight, why the isolation of inhibin presented such a formidable challenge. In the mid-1970s there was no generally accepted 'standard' bioassay procedure for the reliable detection of inhibin-like biological activity (ILA). Rather, the various groups attempting to purify inhibin utilized a range of in-vivo and in-vitro bioassay procedures, each purporting to detect ILA, yet each relying on a different set of assumptions as evidence of their validity (see Baker et al,, 1981; de Jong, 1987). A gradual convergence of opinion as to which of these bioassays afforded the most effective method for the detection and quantitation of ILA (as then defined) led to the widespread adoption of the rat pituitary cell monolayer culture system in which ILA induces a selective fall in the basal release and/or cellular content of FSH. It is 
noteworthy that each of the groups which eventually succeeded in isolating gonadal inhibin used such an assay system for screening chromatographic fractions generated during their purification schemes. In view of the more recent identification in gonadal fluids of molecules other than inhibin which suppress (i.e. follistatin, see below) or stimulate (i.e. activin, see below) pituitary FSH secretion, these rat pituitary cell bioassays should no longer be regarded as specific for inhibin as was once assumed. A second level of complexity with the purification of inhibin arose due to selection by different research groups of a range of ILA-containing gonadal fluids (e.g. porcine, bovine or human FF, ovine rete testis fluid, ovine testicular lymph, seminal plasma) as their respective starting materials. Thirdly, investigators had to contend with the apparent presence in these gonadal fluids of multiple forms of ILA displaying different physico-chemical properties and therefore eluting as confusing multiple peaks and/or poorly resolved components during chromatography. Much of this complexity is now readily explained by proteolytic processing of the high $M_{\mathrm{r}}$ precursor molecules for inhibin to generate biologically-active inhibin molecules differing in size and charge (Mason et al., 1985, 1986; Forage et al., 1986). Finally, inhibin is now recognized as a rather hydrophobic molecule which, unless measures are taken to prevent it, tends to associate not only with other proteins present in crude fluids/extracts but also with certain chromatographic stationary phases, thus giving rise to anomalous and often unpredictable behaviour during chromatography. Whether gonadal and other body fluids contain carrier proteins' which selectively bind inhibin has not yet been established.

A crucial development came in the early 1980s with the recognition that ILA was associated with a remarkably stable molecule capable of regaining its full biological activity following denaturation using harsh dissociating solvents (e.g. containing $8 \mathrm{M}$-urea, $4 \mathrm{M}$-acetic acid or $1 \%$ sodium dodecyl sulphate; SDS). The use of such protein-denaturing solvents to inhibit protein-protein interactions during gel-permeation, ion-exchange and hydrophobic interaction chromatography and the introduction of reversed phase high performance liquid chromatography (RP-HPLC) and preparative SDS-polyacrylamide gel electrophoresis (SDS-PAGE) greatly facilitated the development of effective purification schemes and led directly to the successful isolation of inhibin in 1985 by four independent groups (Robertson et al., 1985; Miyamoto et al., 1985; Ling et al., 1985; Rivier et al., 1985).

\section{Molecular characterization of inhibin}

Initially, Robertson et al. (1985) isolated from bovine FF an $M_{\mathrm{r}} 56000$ form of inhibin which, upon reduction, dissociated into two subunits of $M_{\mathrm{r}} 44000(\alpha 44)$ and $14000(\beta)$. Other groups working with porcine FF (Miyamoto et al., 1985; Ling et al., 1985; Rivier et al., 1985) isolated an $M_{\mathrm{r}}$ 31-32 000 form(s) of inhibin which after reduction yielded $\alpha$ - and $\beta$-subunits of $M_{\mathrm{r}} 18-20000$ and 14-15000, respectively. Robertson et al. (1986) subsequently reported that inclusion of an acidic precipitation step in their purification scheme for bovine FF inhibin resulted in the generation of an $M_{\mathrm{r}} 31000$ form of inhibin which was successfully isolated along with the $M_{r} 56000$ form. Fukuda et al. (1986), using a complex purification scheme identical to that used by their group to isolate pig FF inhibin (Miyamoto et al, 1985), and Knight et al. (1987), using a simplified purification scheme, also isolated an $M_{\mathrm{r}} 32000$ form of inhibin from bovine FF and confirmed that the molecule consisted of two disulphide-linked subunits similar in size to those reported for $M_{\mathrm{r}}$ 31-32000 pig inhibin. An $M_{\mathrm{r}} 30000$ form of inhibin $\left(M_{\mathrm{r}} 21000 \mathrm{\alpha}\right.$-subunit and $M_{\mathrm{r}} 16000$ $\beta$-subunit) was also isolated from ovine follicular fluid (Leversha et al,, 1987). Ling et al. (1985) actually isolated two isoforms of $M_{\mathrm{t}} 32000$ inhibin from pig FF (termed inhibin A and inhibin B) which shared an identical $\alpha$-subunit but had slightly different $\beta$-subunits termed $\beta_{A}$ and $\beta_{B}$ respectively. It was subsequently established that both forms of inhibin $\beta$-subunit are also expressed in human and rat ovary although the $\beta_{\mathrm{B}}$ form has not yet been detected in bovine ovary.

Amino-terminal sequence analysis of the isolated inhibin subunits $\left(\alpha, \beta_{A}\right.$ and $\left.\beta_{B}\right)$ permitted the synthesis of oligonucleotide probes which were then used to isolate from ovarian mRNA libraries, 
cDNA species coding for the $\alpha$ - and $\beta$-subunits of porcine (Mason et al., 1985) and bovine (Forage et al., 1986) inhibin. The cloning and sequencing of these cDNA molecules, accomplished less than 1 year after inhibin was first isolated, enabled the complete amino acid sequence to be predicted for the $\alpha$ - and $\beta$-subunits of porcine (Mason et al., 1985), bovine (Forage et al., 1986), human (Mason et al., 1986) and rat (Woodruff et al., 1987) inhibin. Whilst native gonadal inhibin has not yet been isolated from rat or man, Mason et al. (1987) have reported the expression in Chinese hamster ovary cells of recombinant DNA-derived human inhibin which was biologically active when tested in a rat pituitary cell bioassay.

Although the inhibin concept first arose from studies in the male, progress towards isolating and characterizing testicular inhibin lagged behind that for ovarian inhibin. However, Bardin et al. (1987) and Vaughan et al. (1989) have reported the isolation from ovine rete testis fluid of an $M_{\mathrm{r}} 32000$ form of inhibin which, upon reduction, dissociated into $\alpha$ - and $\beta$-subunits of $M_{\mathrm{r}} 21000$ and 14000 respectively. Amino-terminal sequencing revealed only minor differences compared to the corresponding sequences for pig or bovine ovarian inhibin. Moreover, Bardin et al. (1987) cloned and characterized cDNA encoding the $\alpha$-subunit of inhibin in human testis to reveal a nucleotide sequence identical to that for human ovarian inhibin. Antisera raised against synthetic fragments of ovarian inhibin have been used for immunolocalization studies in testis of several species (Bardin et al., 1987), providing further evidence that ovarian and testicular inhibins are highly homologous.

These molecular characterization studies revealed a striking degree of interspecies homology with respect to inhibin with approximately $85 \%$ homology in the primary structure of the $\alpha$-subunit, $\sim 100 \%$ homology for the $\beta_{A}$ subunit and $>95 \%$ for the $\beta_{B}$ subunit. Moreover, $\alpha^{-}, \beta_{A^{-}}$and $\beta_{B^{-}}$ subunits display similar distribution patterns for cysteine residues, suggesting that they are each derived from a common ancestral gene (Mason et al., 1986). It has also emerged that the $\beta$-subunits of inhibin share considerable homology with a range of proteins implicated in cell differentiation and developmental processes including transforming growth factor $\beta$ (TGF $\beta$ ), Müllerian-inhibiting substance (MIS), an erythroid differentiation factor and activin (see below), giving rise to the concept of the 'inhibin-related peptide family' (see Ying, 1988).

The mature, fully-processed forms of $\alpha-\left(M_{\mathrm{r}} 18-20000\right)$ and $\beta-\left(M_{\mathrm{r}} 14000\right)$ subunits of inhibin constitute the carboxy-termini of much larger precursor molecules composed of about 360 and 420 amino acid residues, respectively (Fig. 1). Each precursor molecule contains a number of potential proteolytic cleavage sites and the locations of these are consistent with the generation of the different $M_{\mathrm{r}}$ forms of inhibin and its subunits identified in gonadal fluids (Robertson et al., 1986; Miyamoto et al., 1986; Knight et al., 1989) and granulosa cell-conditioned culture media (Bicsak et al., 1988). For instance, Miyamoto et al. (1986) used the technique of immunoblotting to demonstrate the presence in bovine FF of $M_{\mathrm{r}} 65000,55000$ and 32000 forms of inhibin dimer. These size differences were attributed to differential processing of the $\alpha$-subunit precursor since, upon reduction, these disulphide-linked dimers yielded immunoreactive $\alpha$-subunits of $M_{\mathrm{r}} 52000$, 42000 and 20000 together with an immunoreactive $\beta$-subunit of constant size $\left(M_{\mathrm{t}} 14000\right)$. These authors also noted the presence of higher $M_{\mathrm{r}}$ forms of inhibin $(120000,108000$ and 88000$)$ which they proposed represented disulphide-linked trimers composed of two processed $\beta$-subunit precursor sequences linked to an $\alpha$-subunit of variable size. These different $M_{\mathrm{r}}$ forms of inhibin appear to possess ILA when eluted from SDS-PAGE gels and tested in an in-vitro inhibin bioassay (Miyamoto et al., 1986) although the possibility exists that, for ILA to be expressed, further processing occurs in the serum-containing culture medium used for the inhibin bioassay, to yield the mature, fully-processed $M_{r} 32000$ dimer. In this regard, McLachlan et al. (1986) showed that, in the presence of serum, $M_{r} 55000$ bovine inhibin is converted to the $M_{\mathrm{r}} 31000$ form which is generally regarded to be the smallest and most predominant form of bioactive inhibin likely to reach the anterior pituitary in vivo.

The mature $M_{\mathrm{r}}$ 18-20000 $\alpha$-subunit of inhibin contains one (bovine, porcine) or two (human) potential $\mathrm{N}$-glycosylation sites in contrast to the mature $\beta$-subunit which lacks such sites (Mason et 


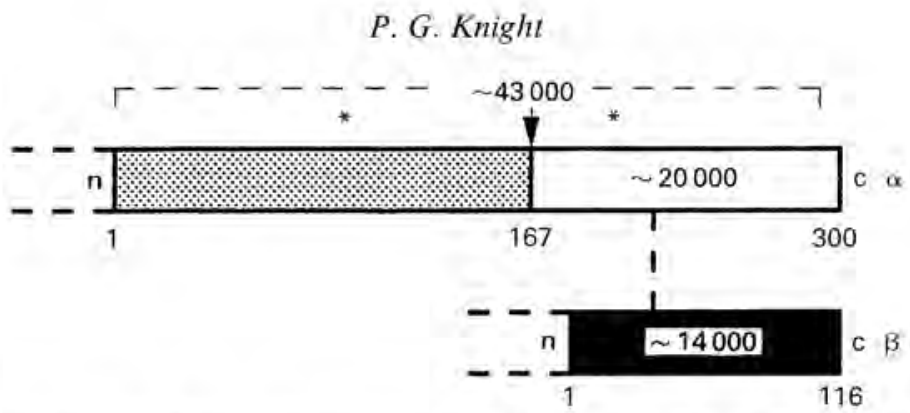

Fig. 1. Diagram showing basic subunit structure of bovine inhibin. Numbers refer to amino acid residues and asterisks indicate approximate positions of potential $\mathrm{N}$-glycosylation sites. $\alpha$ - and $\beta$-subunits are linked by at least one interchain disulphide bond represented by the dashed vertical line. (After Forage et al., 1986,)

al., 1985, 1986; Forage et al., 1986). This factor not only explains the 10-20\% discrepancy between the predicted and observed $M_{\mathrm{r}}$ values for the $\alpha$-subunit but also confirms earlier proposals, based on the behaviour of ILA during lectin affinity chromatography, that inhibin is a glycoprotein (see de Jong, 1988).

\section{Monomeric forms of inhibin $\alpha$-subunit}

Knight et al. (1989) exploited the technique of immunoaffinity chromatography to isolate from bovine FF an abundant and hitherto unrecognized form of inhibin which was highly reactive with antisera raised against either $M, 32000$ inhibin or a synthetic $\alpha$-subunit fragment but which lacked inhibin-like biological activity. Upon SDS-PAGE, this material had an apparent $M_{\mathrm{r}}$ of 25000 under non-reducing conditions, and 21000 under reducing conditions. During amino-terminal sequencing of the isolated material only one amino acid residue was identified at each cycle of Edman degradation and the sequence (1-14) revealed was identical to that reported by Forage et al. (1986) for the amino terminus of the $M_{\mathrm{r}} 20000 \alpha$-subunit of bovine inhibin. The authors attributed the apparently greater $M_{\mathrm{r}}$ value shown by the non-reduced material to anomalous behaviour during SDS-PAGE and concluded that it was a native form of monomeric $M_{\mathrm{r}} 21000 \alpha$-subunit. Independent reports from Sugino et al. (1989) and Robertson et al. (1989) confirmed the presence in bovine FF of 'free' $\alpha$-subunit $\left(M_{\mathrm{r}} 25000\right.$ under non-reducing conditions and 21000 under reducing conditions) devoid of biological activity in inhibin bioassays. Contrary to the conclusion of Knight et al. (1989) however, SDS-PAGE and microsequencing revealed that the isolated material was actually dimeric in nature comprising an $M_{\mathrm{r}} 21000 \alpha$-subunit linked by a disulphide bond to the much smaller 'pro'-region (40 residue amino terminal fragment) of the 'parent' $\alpha$-subunit precursor molecule. Sugino et al. (1989) and Robertson et al. (1989) reasoned that the generation of this molecular species (referred to by the latter group as the 'pro- $\alpha_{c}$ ' fragment) must entail the release by proteolytic excision of the intervening 167 residue fragment. This fragment (referred to as ' $\alpha \mathrm{N}$ ') was successfully isolated from bovine FF by Robertson et al. (1989), confirming the accuracy of this deduction (see Fig. 2).

Such findings emphasize the complexity of potential post-translational processing of inhibin subunit precursor molecules which may generate multiple mono- and dimeric forms, perhaps subserving different biological roles, which have yet to be identified. Indeed, the recent report by Findlay et al. (1989b) that active immunization of ewes against the ' $\alpha \mathrm{N}$ ' fragment impaired fertility suggests it may have a biological role quite distinct from that of inhibin $\alpha \beta$ dimer.

Two forms of 'free' inhibin $\alpha$-subunit $\left(M_{\mathrm{r}} 25000\right.$ and 44000$)$ have been identified in bovine utero-ovarian and jugular venous blood, indicating that these molecules are secreted into the peripheral circulation (Knight et al., 1989). Moreover, these inhibin forms probably represent the dominant immunoreactive species detectable in bovine plasma by currently available inhibin radioimmunoassays. Thus it is now recognized that antisera against synthetic $\alpha$-subunit fragments 


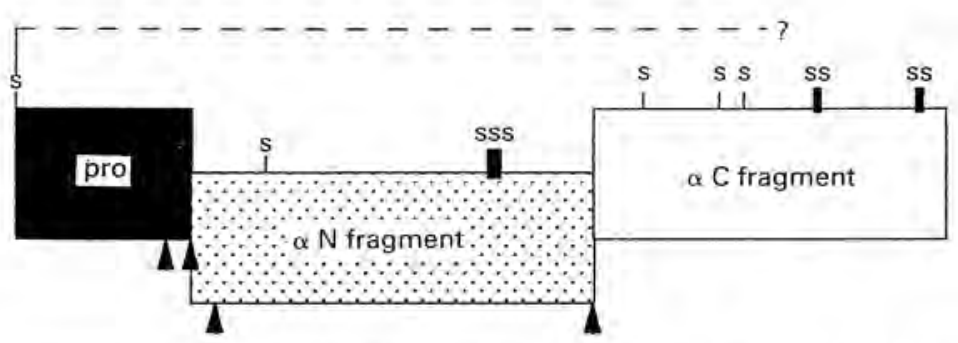

Fig, 2. Processing of inhibin $\alpha$-subunit precursor to yield 'pro" ' $\alpha \mathrm{C}^{\prime}$ ' and ' $\alpha \mathrm{N}$ ' fragments isolated from bovine follicular fluid. Solid triangles indicate potential cleavage sites and $\mathrm{S}$ indicates positions of cystein residues. (Redrawn from Robertson et al., 1989.)

(e.g. Knight et al., 1989; Beard et al., 1990) as well as purified native dimeric inhibin (e.g. Hasegawa et al., 1988; Robertson et al., 1988, 1989) cross-react extensively $(>200 \%)$ with these more recently identified native forms of 'free' $\alpha$-subunit. Clearly, the immunoreactivity of these different forms is strongly influenced by the molecular conformation since 'free' $\alpha$-subunit obtained by reduction and alkylation of purified native inhibin dimer reportedly shows minimal cross-reaction with the same antisera to native inhibin (Robertson et al., 1988).

Attempts in this laboratory to obtain physiologically relevant measurements of circulating concentrations of inhibin in cattle using radioimmunoassay have been hindered not only by the abundant presence of 'free' inhibin $\alpha$-subunit in plasma (Knight et al., 1989) but by the surprising finding that this material persists in the circulation of chronically ovariectomized heifers (see Figs 3 and 4) and steers. Paradoxically plasma levels of immunoreactivity were similar in gonadectomized and intact cattle, suggesting a major extra-gonadal source of this material (Fig. 3). Attempts to identify the source (J. H. M. Wrathall \& P. G. Knight, unpublished observations) have so far been inconclusive although several extra-gonadal tissues of cattle were found to contain immunoassayable levels of inhibin (Fig. 5). Such findings accord with recent reports for other species that mRNA coding for $\alpha$, and to a lesser extent, $\beta$-subunits of inhibin is expressed in various extra-gonadal tissues including adrenal, pituitary, central nervous system and placenta (Crawford et al., 1987; Meunier et al., 1988).

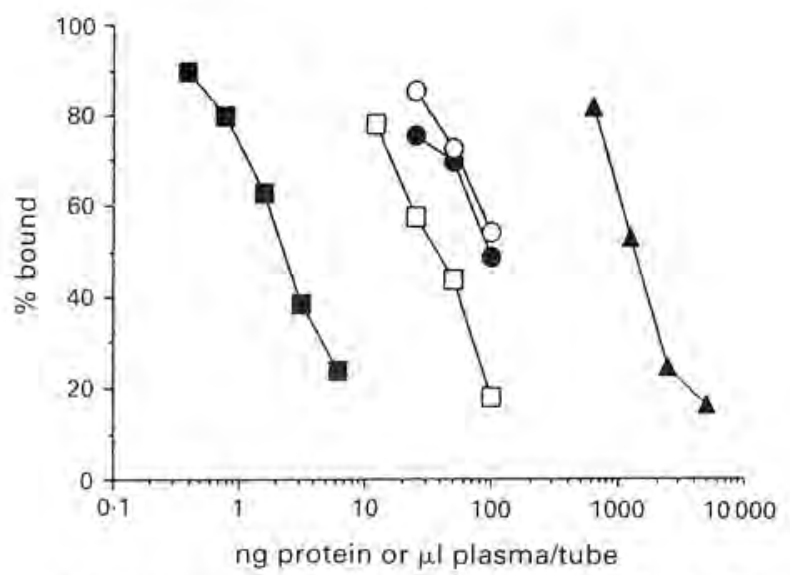

Fig. 3. Comparison of radioimmunoassay displacement curves for highly-purified $M_{\mathrm{r}} 32000$ bovine inhibin ( $\mathbf{E})$, bFF ( $\mathbf{\Lambda})$, bovine utero-ovarian vein plasma ( $\square$ ) and jugular venous plasma from intact $(-)$ and ovariectomized $(O)$ heifers. The assay is based on an antiserum raised in sheep against the $\mathrm{N}$-terminal sequence $(1-32)$ of the $\alpha$-subunit of human inhibin and radioiodinated $M_{\mathrm{r}} 32000$ bovine inhibin is used as the tracer (see Beard et al., 1990). 

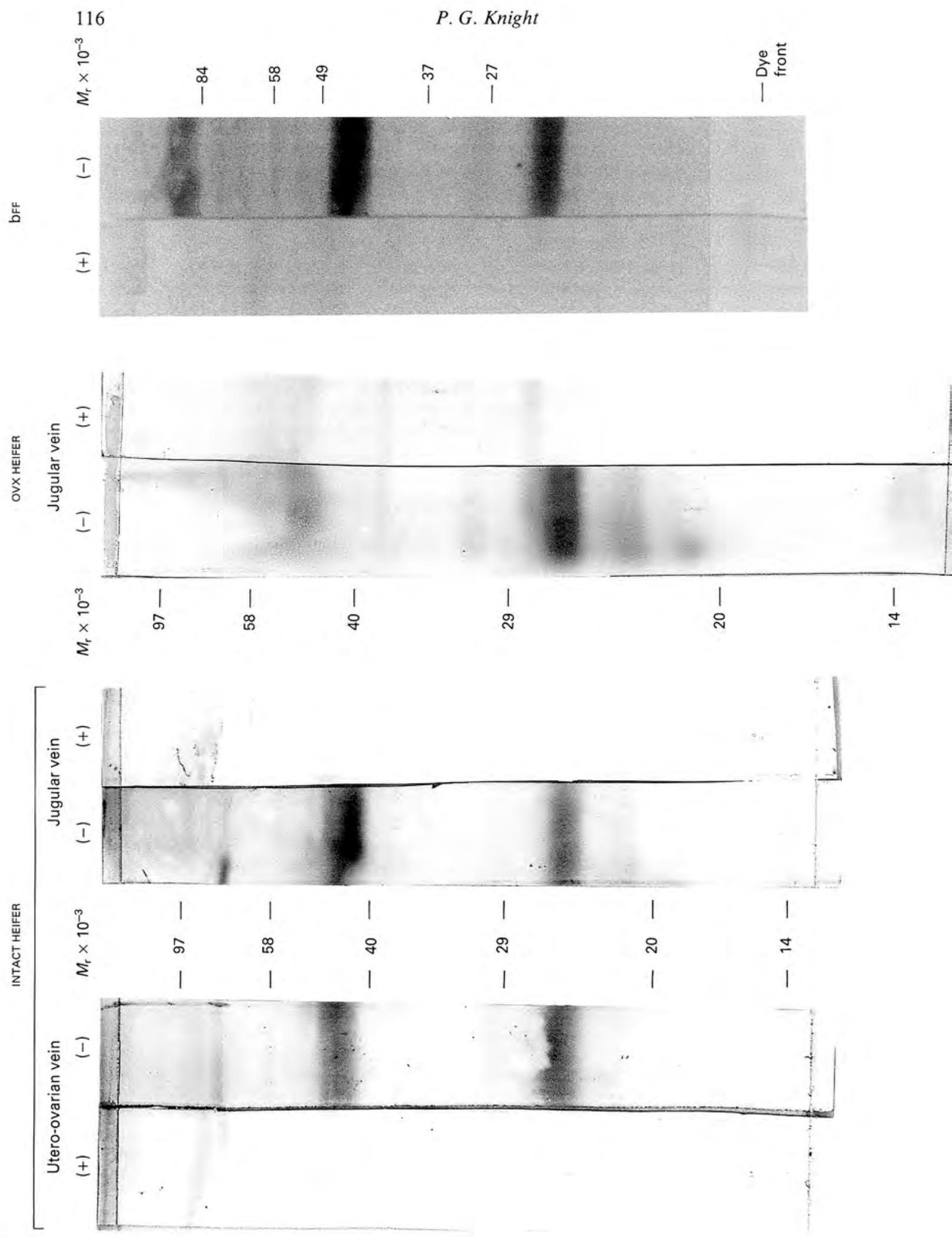
It should be possible to resolve these difficulties associated with the immunochemical measurement of circulating inhibin in cattle, and probably other species, by developing a 2 -site immunoradiometric assay for inhibin in which the specific detection of the analyte (i.e. biologically active inhibin dimer) depends on the recognition of two different antibodies directed against an appropriate pair of epitopes, one on the mature $\alpha$-subunit and the other on the mature $\beta$-subunit (Fig. 6). Whilst excellent $\alpha$-subunit specific antisera are already available, the generation of suitable $\beta$-subunit specific antibodies, which must cross-react with native inhibin dimer, has so far been unsuccessful.

\section{Effects of highly-purified inhibin on gonadotrophin secretion in vivo and in vitro}

Whilst the recent availability of highly-purified inhibin has encouraged detailed in-vitro investigations into its actions on cultured rat pituitary cells, the prospect of undertaking similarly detailed 'whole animal' studies is hindered by the strictly limited amounts of inhibin currently available. However, three in-vivo studies, involving intact rats (Ying et al., 1987), ovariectomized ewes (Findlay et al., 1987) and ovariectomized heifers (Beard et al., 1990) have now confirmed that highly-purified inhibin preparations do indeed suppress plasma FSH concentrations with little or no effect on plasma $\mathrm{LH}$.

Initial claims that the effect of highly purified inhibin on cultured rat gonadotrophs is confined to a specific reduction in FSH cell content and release (Ling et al., 1985; Fukuda et al., 1986; Robertson et al., 1986) have now been revised following more recent demonstrations that both basal (Farnworth et al., 1988a; Castillo, 1989) and GnRH-induced (Fukuda et al., 1987; Farnworth et al., 1988b; Campen \& Vale, 1988; Castillo, 1989) LH release may also be suppressed, albeit to a lesser extent than FSH. The latter observation is in accordance with the observation by Wang et al. (1988) that exposure of rat pituitary cells to inhibin reduces the number of GnRH receptors.

Whilst it would be tempting to extrapolate these in-vitro findings for the rat to other species, including ruminants, we have shown (Muttukrishna \& Knight, 1990) that exposure of cultured sheep pituitary cells to highly-purified bovine inhibin actually enhances $\mathrm{GnRH}$-induced LH release without affecting basal LH release; basal and GnRH-induced FSH release were suppressed by inhibin, in a manner similar to that observed in rats (Fig. 7). There are already indications, therefore, that the actions of inhibin and related proteins on the ruminant pituitary may differ from those identified for the rat, a view reinforced by our subsequent observation (see Fig. 8) that activin stimulates basal LH release but suppresses $\mathrm{GnRH}$-induced LH release from ovine pituitary cells in vitro.

\section{Activin}

\section{Identification and purification of activin}

Whilst developing procedures to isolate inhibin from pig FF two independent groups (Ling et al., 1986; Vale et al, 1986) observed that certain fractions obtained during gel permeation chromatography and HPLC appeared to stimulate, rather than suppress, FSH secretion in vitro.

Fig. 4. Analysis by 'Western blotting' of crude bovine follicular fluid (bFF) and immunoaffinity-purified serum extracts from intact and ovariectomized (OVX) heifers. Samples were subjected to SDS-PAGE under non-reducing conditions and immunoblotting was performed using an antibody raised in a rabbit against the $\mathrm{N}$-terminal sequence $(1-32)$ of the $\alpha$-subunit of human inhibin. Specificity of immunostaining was confirmed by incubating each sample with antibody in the absence $(-)$ and presence $(+)$ of an excess of a synthetic peptide mimicking the $\mathrm{N}$-terminal sequence (1-29) of the $\alpha$-subunit of bovine inhibin. The positions of molecular weight markers are indicated. 


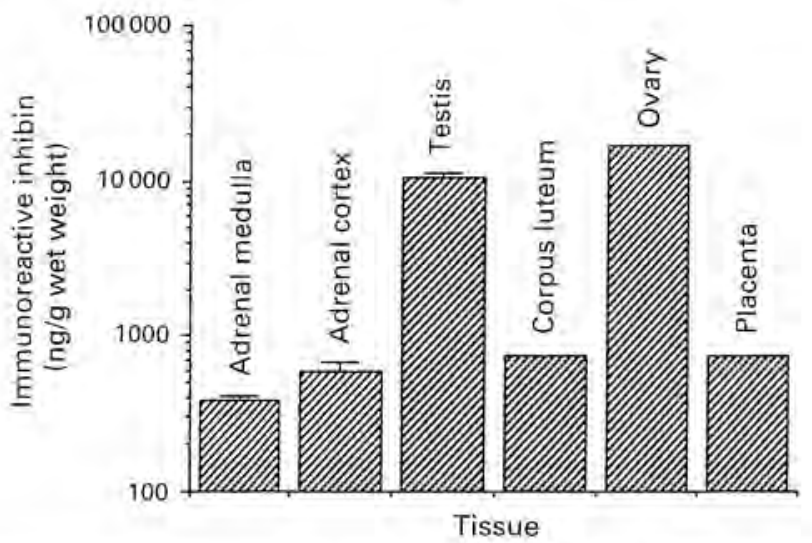

Fig. 5. 1mmunoreactive inhibin contents of various bovine tissues. With the exception of corpus luteum, ovary and placenta which represent single observations, values are means \pm s.e.m. $(n=6)$. Other tissues analysed, including hypothalamus, pituitary, thymus, heart, kidney, liver and spleen $(n=6)$, had inhibin levels below the limit of detection of the assay $(<80 \mathrm{ng} / \mathrm{g})$. (Unpublished observations of J. H. M. Wrathalt \& P. G. Knight.)

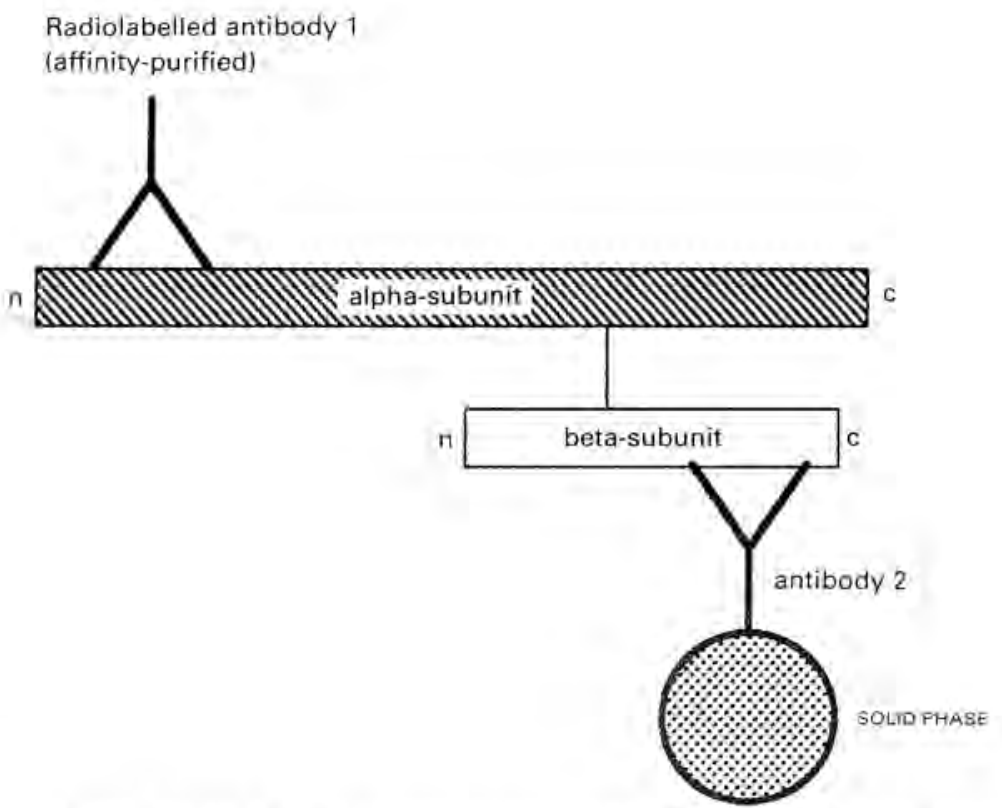

Fig. 6. Potential application of a 2-site immunoradiometric assay for the specific quantitation of dimeric (i.e. bioactive) inhibin.

Both groups went on to isolate and characterize the active substance(s), revealing them to be disulphide-linked dimeric proteins actually composed of two inhibin $\beta$-subunits (either a $\beta_{A} \beta_{B}$ heterodimer, termed 'activin' or a $\beta_{\mathrm{A}} \beta_{\mathrm{A}}$ homodimer now termed 'activin-A'). Activin-A was subsequently isolated from bovine FF (Hutchinson et al., 1987). It also emerged that an erythroid differentiation factor isolated from a human leukaemia cell line is, in fact, identical to activin-A (Eto et al., 1987). 
(a) Basal release

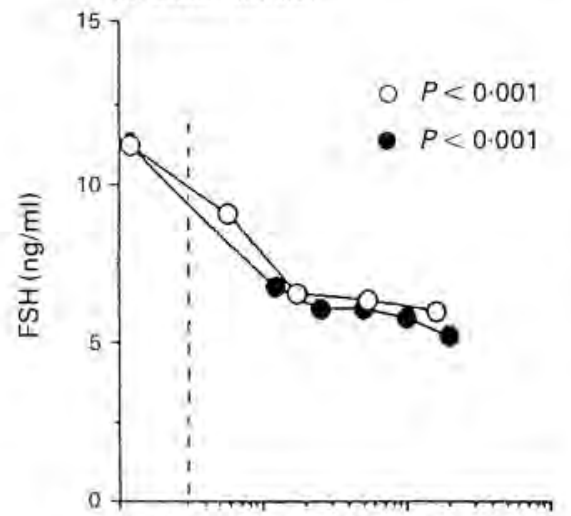

(b) GnRH-induced release

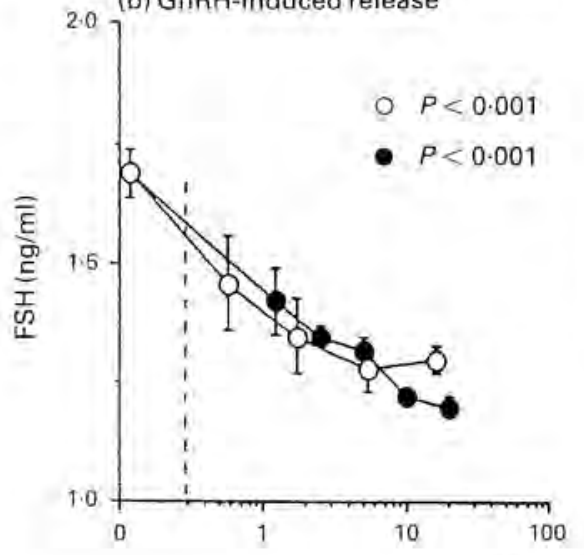

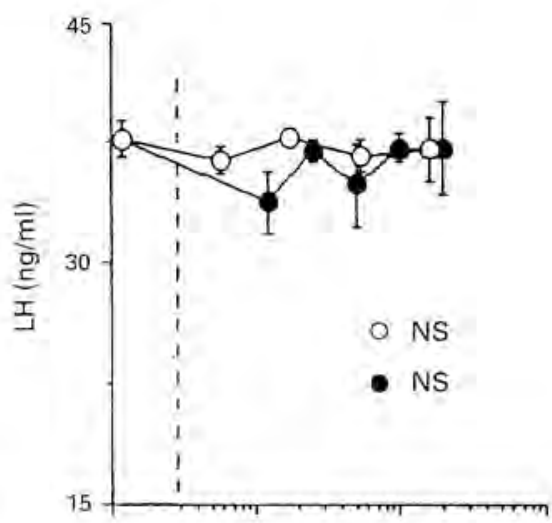

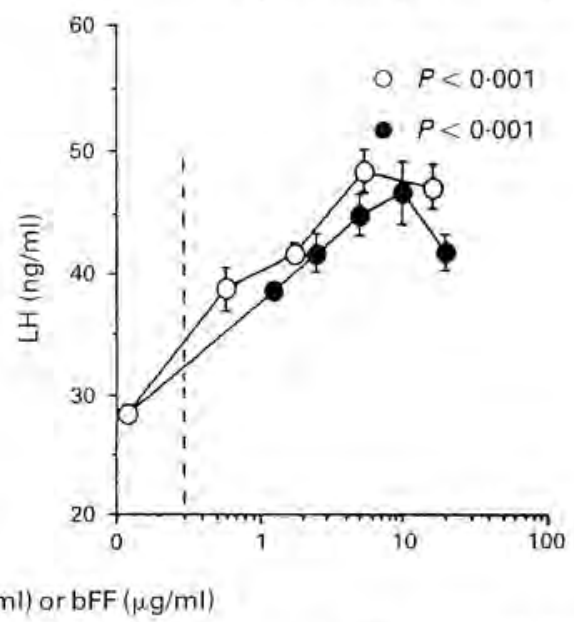

Fig. 7. Effects of highly purified $M_{\mathrm{r}} 32000$ bovine inhibin ( ) and bovine follicular fluid (bFF, o) on (a) basal and (b) GnRH-induced release of FSH and LH by ovine pituitary cells in vitro. Values are means $(n=4)$ and vertical bars indicate s.e.m. where this exceeds the symbol width. $P$ values indicate a significant dose-dependent effect of each treatment (ANOVA). NS, not significant by ANOVA. (From Muttukrishna \& Knight, 1990.)

\section{Biological properties}

In terms of their biological activity activin and activin-A are approximately equipotent, stimulating basal FSH secretion by cultured rat pituitary cells $\left(\mathrm{ED}_{50} \sim 1 \mathrm{ng} / \mathrm{ml}\right)$ without affecting the secretion of LH, TSH or prolactin. This effect of activin on pituitary FSH secretion is antagonized by inhibin. Schwall et al. (1989) recently reported the production of recombinant human activin-A which stimulates FSH secretion by rat pituitary tissue in vitro and in vivo without affecting LH release. Regarding the question of whether activin affects gonadotrophin secretion in ruminants, we have shown that, as in rats, recombinant human activin-A stimulates both basal and GnRH-induced secretion of FSH by sheep pituitary cells in vitro (S. Muttukrishna \& P. G. Knight, unpublished observations). However, whilst activin-A also stimulated basal LH release, we were surprised to find that it actually suppressed GnRH-induced LH release, a novel action at variance with reports for the rat (Fig. 8). In view of the functional antagonism between inhibin and activin, this observation adds credence to our earlier finding reported above that inhibin enhances $\mathrm{GnRH}$ induced LH release by sheep pituitary cells in vitro (see Fig. 7). These observations highlight the need for further comparative investigations in species other than the rat, which has, to date, been 
(a) Basal release

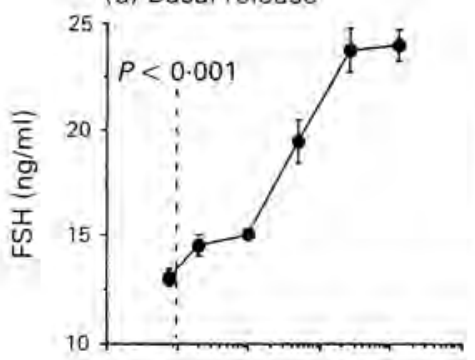

(b) GnRH-induced release

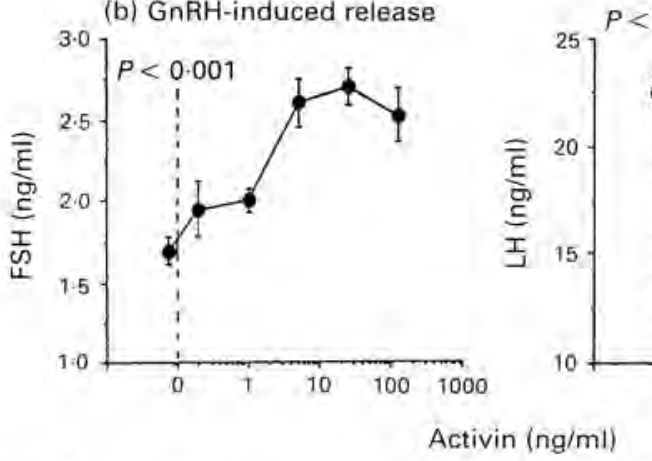

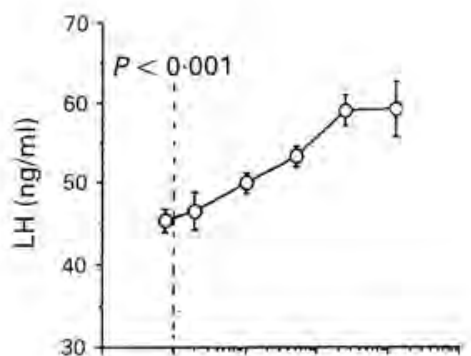

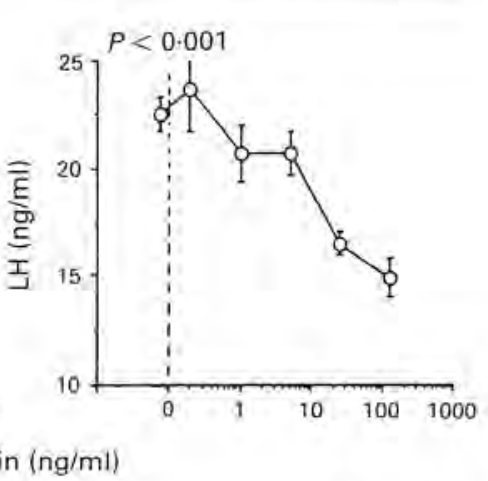

Fig. 8. Effect of recombinant human activin-A on (a) basal and (b) GnRH-induced release of FSH $(\bullet)$ and LH $(O)$ by ovine pituitary cells in vitro. Values are means $(n=4)$ and vertical bars indicate s.e.m. $P$ values indicate a significant dose-dependent effect of treatment. (Unpublished observations of S. Muttukrishna \& P. G. Knight.)

used almost exclusively for in-vitro testing of inhibin and inhibin-related proteins. It is not yet known for any species whether activin of ovarian origin circulates as a hormone to modify pituitary gonadotrophin secretion. There is, however, ample evidence, at least for the rat, that it acts at the intraovarian level to modulate granulosa cell function (Ying, 1988; la Polt et al., 1989).

\section{Follistatin}

\section{Identification and purification}

Ueno et al. (1987) noted that a further zone of ILA, distinct from the inhibins, was resolved by the first reversed-phase HPLC fractionation step of their inhibin-purification scheme. After three more HPLC steps they isolated a monomeric $M_{\mathrm{r}} 35000$ protein which was found to share no homology with either $\alpha$ - or $\beta$-subunits of inhibin and which they termed follistatin. A less abundant $M_{\mathrm{r}} 32000$ molecular variant of follistatin was also isolated from the same source and found to have an amino terminal sequence identical to the $M_{\mathrm{r}} 35000$ molecule. Molecular cloning techniques allowed the complete primary structure of the pig follistatin precursor to be deduced (Esch et al., 1987) and the pig cDNA probes were subsequently used to characterize the human follistatin precursor, revealing only 6 amino acid substitutions between the two species (Shimasaki et al., 1988). Regarding the production of follistatin by the ruminant ovary, Robertson et al. (1987) isolated from bovine FF three closely-related molecules with FSH-suppressing activity which were each shown to have the same amino terminal sequence as porcine follistatin. Moreover, Leversha et al. (1987) reported the presence of a non-reducible $M_{\mathrm{r}} 36000$ molecule with ILA (presumed to be follistatin) in ovine FF. 


\section{Biological properties}

Porcine and bovine follistatins specifically suppress FSH production (release or cell content) by cultured rat pituitary cells in vitro but with a potency only $10-30 \%$ that of purified inhibin (Robertson et al., 1987; Ueno et al., 1987; Esch et al., 1987). It remains to be established whether follistatin exerts similar effects on pituitary gonadotrophs from ruminant species. Furthermore, it is not known whether this putative hormone reaches the peripheral circulation in amounts capable of influencing pituitary gonadotroph function in vivo although there are recent indications that it acts intragonadally to modify ovarian steroid output (Findlay et al., 1989a). Attempts to measure circulating concentrations of follistatin must await the development of specific radioimmunological assays since, as mentioned above, conventional bioassay procedures, as well as lacking sensitivity, are unable to discriminate between inhibin and follistatin.

I thank AFRC for financial support; NIADDK for RIA reagents; Genentec Inc. for recombinant human activin-A; and Mrs S. Dalton for typing the MS.

\section{References}

Baker, H.W.G., Eddie, L.W., Higginson, R.E., Hudson, B., Keogh, E.J. \& Niall, H.D. (1981) Assays of inhibin. In Intragonadal Regulation of Reproduction, pp. 193228. Eds P. Franchimont \& C. P. Chânning. Academic Press, London.

Bardin, C.W., Morris, P.L., Chen, C-L., Shaha, C., Voglmayr, J., Rivier, J., Spiess, J. \& Vale, W.W. (1987) Testicular inhibin: structure and regulation by FSH, androgens and EGF. In Inhibin: Non-steroidal Regulation of Follicle Stimulating Hormone Secretion (Serono Symp. Vol. 42), pp. 179-190. Eds H. G. Burger, D. M. de Kretser. J. K. Findlay \& M. Igarashi. Raven, New York.

Beard, A.J., Castillo, R.J., McLeod, B.J., Glencross, R.G. \& Knight, P.G. (1990) Comparison of the effects of crude and highly-purified bovine inhibin $(M, 32,000)$ on plasma concentrations of FSH and LH in chronically ovariectomized prepubertal heifers. $J$. Endocr. 125, 21-30.

Bicsak, T.A., Cajander, S.B., Vale, W. \& Hsueh, A.J.W. (1988) Inhibin: studies of stored and secreted forms of biosynthetic labeling and immunodetection in cultured rat granulosa cells. Endocrinology 122, $741-748$.

Burger, H.G. (1988) Inhibin definition and nomenclature including related substances. J. Endocr. 117, $159-160$.

Castillo, R.J. (1989) Bioassay and isolation of bovine ovarian inhibin and its effects on gonadotrophin secretion. Ph.D. thesis, University of Reading.

Campen, C.A. \& Vale, W. (1988) Interaction between purified ovine inhibin and steroids on the release of gonadotropins from cultured rat pituitary cells. Endocrinology 123, 1320-1328.

Crawford, R.J., Hammond, V.E., Evans, B.H., Coghlan, J.P., Harlambidis, J., Hudson, B., Penschow, J.D., Richards, R.I. \& Tregear, G.W (1987) $\alpha$-Inhibin gene expression occurs in the ovine adrenal cortex and is regulated by adrenocorticotropin. Molec, Endoct. 1, 699-706.

de Jong, F.H. (1987) Inhibin. Oxford Rev. Reprod. Biol. 9, 1-53.

de Jong, F.H. (1988) Inhibin. Physiol. Rev. 68, 555-607.
Esch, F.S., Shimasaki, S., Mercado, M., Cooksey, K., Ling, N., Ying, S-Y., Ueno, B. \& Guillemin, R. (1987) Structural characterization of follistatin: a novel follicle-stimulating hormone release-inhibiting polypeptide from the gonad. Molec. Endocr. 1, 849-855.

Eto, Y., Tsuji, T., Takezawa, M., Takano, S., Yokogawa, Y. \& Shibai, H. (1987) Purification and characterization of erythroid differentiation factor (EDF) isolated from human leukaemia cell line THP-1. Biochem. Biophys. Res. Commun, 42, 1095-1103.

Farnworth, P.G., Robertson, D.M., de Kretser, D.M. \& Burger, H.G. (1988a) Effects of $3 I$ Kilodalton bovine inhibin on follicle stimulating hormone and luteinizing hormone in rat pituitary cells in vitro: actions under basal conditions. Endocrinology 122, 207-213.

Farnworth, P.G., Robertson, D.M., de Kretser, D.M. \& Burger, H.G. (1988b) Effects of $31 \mathrm{kDa}$ bovine inhibin on FSH and LH release in rat pituitary cells in vitro: antagonism of gonadotrophin-releasing hormone mone agonists. J. Endocr. 119, 233-241.

Findlay, J.K. (1986) The nature of inhibin and its use in the regulation of fertility and diagnosis of infertility. Fert. Steril. 46, 770-783.

Findlay, J.K., Robertson, D.M. \& Clarke, I.J. (1987) Influence of dose and route of administration of bovine follicular fluid and the suppressive effect of purified bovine inhibin $\left(\mathrm{M}_{\mathrm{r}} 31,000\right)$ on plasma FSH concentrations in ovariectomized ewes. J. Reprod. Fert. 80, 455-461.

Findlay, J.K., Sai, X. \& Robertson, D.M. (1989a) Effects of follistatin on the differentiation of rat granulosa cells in culture. J. Reprod. Fert., Abstr. Ser. 3, Abstr. 38.

Findlay, J.K., Tsonis, C.G., Doughton, B., Brown, R.W., Bertram, K.C., Braid, G.H., Hudson, G.C., Tierney, M.L., Goss, N.H. \& Forage, R.G. (1989b) Immunization against the amino terminal peptide $\left(\alpha_{N}\right)$ of the alpha $_{43}$ subunit of inhibin impairs fertility in sheep. Endocrinology 124, 3122-3124.

Forage, R.G., Ring, J.M., Brown, R.W., McInerney, B.V., Cobon, G.S., Gregson, R.P., Robertson, D.M., Morgan, F.J., Hearn, M.T.W., Findlay, J.K., Wettenhall, R.E.H., Burger, H.G. \& de Kretser, D.M. 
(1986) Cloning and sequence analysis of cDNA species coding for the two subunits of inhibin from bovine follicular fluid. Próc, nain, Acad. Sci. USA 83, 3091-3095.

Fukuda, M., Miyamoto, K., Hasegawa, Y., Nomura, M., Igarashi, M., Kangawa, K. \& Matsuo, H. (1986) Isolation of bovine follicular fluid inhibin of about $32 \mathrm{kDa}$. Molec. cell. Endocr. 44, 55-60.

Fukuda, M., Miyamoto, K., Hasegawa, Y., Tbuki, Y. \& Igarashi, M. (1987) Action mechanism of inhibin in vitro-cyclohexamide mimics inhibin actions on pituitary cells. Molec, cell. Endocr. 51, 41-50.

Hasegawa, Y., Miyamoto, K., Iwamura, S. \& Igarashi, M. (1988) Changes in serum concentrations of inhibin in cyclic pigs. $J$. Endocr. 118, 211-219.

Hutchinson, L.A., Findlay, J.K., de Vos, F.L. \& Robertson, D.M. (1987) Effects of bovine inhibin. transforming growth factor $\beta$ and bovine activin-A on granulosa cell differentiation. Biochem. Biophys. Res. Commun. 146, 1405-1412.

Knight, P.G., Beard, A.J., Wrathall, J.H.M. \& Castillo, R.J. (1989) Evidence that the bovine ovary secretes large amounts of inhibin $\alpha$-subunit and its isolation from bovine follicular fiuid. $J$. molec, Endocr, 2, 189-200.

Knight, P.G., Castillo, R.J. \& Glencross, R.G. (1987) Isolation from bovine follicular fiuid (bFF) of a $32 \mathrm{kDalton}$ molecule with potent inhibin-like biological activity (ILA). J. Endocr. 112 (Suppl.), Abstr. 52.

la Polt, P.S., Soto, D., Su, J-G., Campen, C.A., Vaughan, J., Vale, W. \& Hsueh, A.J.W. (1989) Activin stimulation of inhibin secretion and messenger RNA levels in cultured granulosa cells. Molec. Endocr. 3, 1666 1673.

Leversha, L.J., Robertson, D.M., de Vos, F.L., Morgan, F.J., Hearn, M.T.W., Wettenhall, R.E.H., Findlay, J.K., Burger, H.G. \& de Kretser, D.M. (1987) Isolation of inhibin from ovine follicular fluid. J. Endocr. 113, 213-221

Lincoln, D.W., McNeilly, A.S. \& Sharpe, R.M. (1989) Reproductive physiology of inhibin and related peptides. In Recent Advances in Endocrinology and Metabolism, pp. 77-107. Eds C. R, Edwards \& D. W. Lincoln. Churchill Livingstone, Edinburgh.

Ling, N., Ying, S.-Y., Ueno, N., Esch, F., Denoroy, L. \& Guillemin, R. (1985) Isolation and partial characterization of $\mathrm{Mr} 32000$ protein with inhibin activity from porcine follicular fluid. Proc: natn. Acad. Sci. USA 82, 7217-7221.

Ling, N., Ying, S.-Y., Uneo, N., Shimasaki, S., Esch, F., Hotta, M. \& Guillemin, R. (1986) Pituitary FSH is released by a heterodimer of the $\beta$-subunits from the two forms of inhibin. Nature, Lond. 321, 779-782.

Mason, A.J., Hayflick, J.S., Ling, N., Esch, F., Ueno, N. Ying, S.-Y., Guillemin, R., Niall, H. \& Seeburg, P.H. (1985) Complementary DNA sequences of ovarian follicular fluid inhibin show precursor structure and homology with transforming growth factor-B. Nature. Lond 318, 659-663.

Mason, A.J., Niall, H.D. \& Seeburg, P.H. (1986) Structure of two human ovarian inhibins. Biochem. Biophys. Res. Commun. 135, 957-964.

Mason, A.J., Schwall, R., Reuz, M., Rhee, L.M., Nikolics, K. \& Seeburg, P.H. (1987) Human inhibin and activin: structure and recombinant expression in mammalian cells. In Inhibin: Non-steroidal Regulation of Folliclestimulating Hormone Secretion (Serono Symp. vol. 42), pp. 77-88. Eds H. G. Burger. D. M. de Kretser, J. K. Findlay \& M. Igarashi. Raven Press, New York.

McCullagh, D.R. (1932) Dual endocrine activity of the testes. Science, $N Y \mathbf{7 6}, 19-20$.

MeLachlan, R.I., Robertson, D.M., Burger, H.G. \& de Kretser, D.M. (1986) The radioimmunoassay of bovine and human follicular fluid and serum inhibin. Molec, Cell. Endocr. 46, 175-185.

Meunier, H., Rivier, C., Evans, R.M. \& Vale, W. (1988) Gonadal and extragonadal expression of inhibin $\alpha$, $\beta-A$ and $\beta-B$ subunits in various tissues predicts diverse functions. Proc, natn. Acad. Sci. USA 85, $247-251$

Miyamoto, K., Hasegawa, Y., Fukuda, M., Nomura, M., Igarashi, M., Kangawa, K. \& Matsuo, H. (1985) Isolation of porcine follicular fluid inhibin of 32 kDaltons. Biochem. Biophys. Res. Commum. 129. 396- 403 .

Miyamoto, K., Hasegawa, Y., Fukuda, M. \& Igarashi, M. (1986) Demonstration of high molecular weight forms of inhibin in bovine follicular fluid (bFF) by using monoclonal antibodies to bFF $32 \mathrm{k}$ inhibin. Biochem. Biophys. Res. Commun. 136, 1103-1109.

Mottram, J.C. \& Cramer, W. (1923) On the general effects of exposure to radium on metabolism and tumour growth in the rat and the special effects on testis and pituitary. Q. J.exp. Physiol. 13, 209-229.

Muttukrishna, S. \& Knight, P.G. (1990) Effects of crude and highly-purified bovine inhibin (M, 32000 form) on gonadotrophin production by ovine pituitary cells in vitro: inhibin enhances gonadotrophin releasing hormone-induced release of LH. $J$. Endocr. 127, 149-159.

Rivier, J., Spiess, J., McClintock, R., Vaughan, J. \& Vale, W. (1985) Purification and partial characterization of inhibin from porcine follicular fluid. Biochem. Biophys. Res. Commin. 133, 120-127.

Robertson, D.M., Foulds, M.L., Leversha, L., Morgan, F.J., Hearn, M.T.W., Burger, H.G., Wettenhall, R.E.H. \& de Kretser, D.M. (1985) Isolation of inhibin from bovine follicular fluid. Biochem. Biophys. Res. Commun. 126, 220-226.

Robertson, D.M., de Vos, F.L., Foulds, L.M., Burger, H.G., Morgan, F.J., Hearn, M.T.W. \& de Kretser, D.M. (1986) Isolation of a $31 \mathrm{kDa}$ form of inhibin from bovine follicular fluid. Moles. cell. Endocrinol. 44, $271-277$.

Robertson, D.M., Klein, R., de Vos, F.L., McLachlan, R.I., Wettenhall, R.E.H., Hearn, M.T.A., Burger, H.G. \& de Kretser, D.M. (1987) The isolation of polypeptides with FSH suppressing activity from bovine follicular fluid which are structurally different to inhibin. Biochem. Biophys. Res. Commun. 149,744-749.

Robertson, D.M., Hayward, S., Irby, D., Jacobsen, J., Clarke, L., McLachlan, R.I. \& de Kretser, D.M. (1988) Radioimmunoassay of rat serum inhibin: changes after PMSG-stimulation and gonadectomy. Molec. cell. Endocr. 58, 1-8.

Robertson, D.M., Giacometti, M., Foulds, L.M., Lahnstein, J., Goss, N.H., Hearn, M.T.W. \& de Kretser, D.M. (1989) Isolation of inhibin $\alpha$-subunit precursor proteins from bovine follicular fluid. Endocrinology 125, 2141-2149. 
Schwall, R., Schmelzer, C.H., Matsuyawa, E. \& Mason, A.J. (1989) Multiple actions of recombinant activin-A in vivo. Endocrinology 125, 1420-1423.

Shimasaki, S., Koga, M., Esch, F., Cooksey, K., Mercado, M., Koba, A., Veno, N., Ying, S-Y, Ling, N. \& Guillemin, R. (1988) Primary structure of the human follistatin precursor and its genomic organization. Proc, natn. Acad. Sci. USA 85, 4218-4222.

Sugino, K., Nakamura, T., Takio, K., Titani, K., Miyamoto, K., Hasegawa, T., Igarashi, M. \& Sugino, H. (I989) Inhibin alpha-subunit monomer is present in bovine follicular fluid. Biochem. Biophys. Res. Commun. 159, 1323-1329.

Ueno, N., Ling, N., Ying, S.-Y., Esch, F., Shimasaki, S. \& Guillemin, R. (1987) Isolation and partial characterization of follistatin, a novel $M_{r} 35,000$ monomeric protein which inhibits the release of folliclestimulating hormone. Proc nam. Acad. Sci. USA 84, 8282-8288.

Vale, W., Rivier, J., Vaughan, J., McClintock, R., Corrigan, A., Wood, W., Karr, D. \& Spiess, J. (1986) Purification and characterization of an FSH releasing protein from porcine ovarian follicular fluid. Nature, Lond. 321, 776-779.
Vaughan, J.M., Rivier, J., Corrigan, A.Z., McClintock, R., Campen, C.A., Jolley, D., Voglmayr, J.K., Bardin, C.W., Rivier, C. \& Vale, W. (1989) Detection and purification of inhibin using antisera generated against synthetic peptide fragments. In Methods in Enzymology, vol. 168, pp. 588-617. Ed. P. M. Conn. Academic Press, New York.

Wang, Q.F., Farnworth, P.G., Findlay, J.K. \& Burger, H.G. (1988) Effect of purified $31 \mathrm{k}$ bovine inhibin on the specific binding of gonadotropin-releasing hormone to rat anterior pituitary cells in culture. Endocrinology 123,2161-2166.

Woodruff, T.K., Meunier, H., Jones, P.B.C., Hsueh, A.J.W. \& Mayo, K.E. (1987) Rat inhibin: molecular cloning of $\alpha$ and $\beta$-subunit complementary deoxyribonucleic acids and expression in the ovary. Molec. Endocr. 1, 561-568.

Ying, S.-Y. (1988) Inhibins, activins and follistatins: gonadal proteins modulating the secretion of folliclestimulating hormone. Endocr. Rev. 9, 267-293.

Ying, S.-Y., Czvik, J., Becker, A., Ling, N., Ueno, N. \& Guillemin, R. (1987) Secretion of follicle stimulating hormone and production of inhibin are reciprocally related. Proc. natn. Acad, Sci, USA 84, 4631-4635. 